\title{
PENINGKATAN HASIL BELAJAR KIMIA SISWA MELALUI METODE EKSPERIMEN
}

\author{
Orde Baru1, Leony Sanga Lamsari Purba ${ }^{2 *}$, St Fatimah Azzahra ${ }^{3}$ \\ ${ }^{12}$ Program Studi Pendidikan Kimia, Universitas Kristen Indonesia. Jalan Mayjen Stoyo No. 2 \\ Cawang, Jakarta Timur, DKI Jakarta, 13630, Indonesia. \\ * Coressponding Author. E-mail: leony.purba@uki.ac.id
}

Received: 11 Mei 2021

Accepted: 30 November 2021 Published: 30 November 2021 doi: 10.29303/cep.v4i3.2654

\begin{abstract}
Abstrak
Penelitian quasi exsperiemen ini bertujuan untuk mengetahui peningkatan hasil belajar kimia siswa melalui metode eksperimen. Rancangan penelitian yang digunakan adalah prettest posttest control group design. Populasi penelitian ini adalah seluruh siswa SMA Widya Manggala. Sampel dkelas X MIA1 sebagai kelas eksperimen dan X MIA2 sebagai kelas kontrol diperoleh melalui teknik purposive sampling. Berdasarkan hasil penelitian, pada kelas eksperimen skor pretes terendah 25 dan skor tertinggi 65 dengan rata-rata 42,2. Sedangkan skor postes di kelas eksperimen terendah 65 dan tertinggi 95 dengan rata-rata 73,12. Hasil hipotesis data pretes dan postes kelas eksperimen di dapatkan thitung sebesar 8,147< $t_{\text {tabel }}$ sebesar 2,131. Pengolahan data menunjukkan bahwa nilai Sig. (2-tailed) $<0,05$ sehingga $H_{a}$ diterima dan $\mathrm{H}_{\mathrm{o}}$ ditolak. Jadi dapat disimpulkan bahwa ada peningkatan hasil belajar kimia siswa melalui metode eksperimen.
\end{abstract}

Kata Kunci : Hasil belajar, Kimia, Metode Eksperimen

\section{Improving Students' Chemistry Learning Outcomes Through Experimental Method}

\begin{abstract}
This quasi experiment study aims to determine the increase in student learning outcomes chemistry through the experimental method. The research design used was prettest posttest control group design. The population of this research is all students of SMA Widya Manggala. The sample class X MIA1 as the experimental class and X MIA2 as the control class was obtained through purposive sampling technique. Based on the research results, in the experimental class the lowest pretest score was 25 and the highest score was 65 with an average of 42.2. While the lowest post-test score in the experimental class was 65 and the highest was 95 with an average of 73.12. The results of the pretest and posttest experimental class data hypotheses obtained $t_{\text {count }}$ of $8.147<t_{\text {table }}$ of 2.131 . Data processing shows that the value of Sig. (2-tailed) $<0.05$ so that Ha is accepted and Ho is rejected. So it can be concluded that there is an increase in students' chemistry learning outcomes through the experimental method.
\end{abstract}

Keywords: Learning Outcomes, Chemistry, Experimental Methods

\section{PENDAHULUAN}

Konsep pendidikan pada dasarnya membuat peserta didik memiliki kompetensi lulusan yang sesuai dengan jenjang pendidikan yaitu pengetahuan, nilai, sikap, dan kemampuan bertanggung jawab dalam melaksanakan tugas. Hal ini berhubungan dengan tujuan pendidikan nasional No. 20 tahun 2003, tentang Pendidikan Nasional (Undang-Undang Sisdiknas), bertujuan mengembangkan potensi siswa. Guru sebagai pendidik berperan dalam menongkatkan potensi siswa. Menurut Purba (2018), pembelajaran kimia yang baik akan meningkatkan minat belajar siswa. Selain minat siswa, menurut Junita dan Purba (2019), pembelajaran kimia yang yang terencana mampu meningkatkan hasil belajar siswa. Seluruh kemampuan guru dalam mengembangkan potensi anak tergantung pada kompetendi yang dimiliki seorang guru (Secara umum kompetensi menurut UU No. 14 Tahun 2005 pasal 10 ayat 1 meliputi pedagogik, 
kepribadian, sosial, dan profesioanal. Tugas keprofesional guru salah satunya untuk merencanakan pembelajaran serta melaksanakan pembelajaran yang bermutu, serta menilai dan mengevaluasi.

Pembelajaran yang guru oriented mengakibatkan siswa kurang aktif dalam proses pembelajaran, hal ini lah salah satu penyebab siswa tidak maksimal meningkatkan kompetensi yang dimilikinya (Purba, 2014). Hasil belajar siswa merupakan gambaran secara holistik pencapaian siswa setelah pembelajaran (Sustrisno, 2016). Hasil belajar yang rendah diakibatkan (1) cara penyampaian guru yang kurang meningkatkan pemahaman siswa (Anwar,2019); (2) Diskusi yang pasif (Islamiati, dkk., 2020) dan (3) siswa kurang dilibatkan dalam pembelajaran (Widodo \& Widayanti, 2013).

Peningkatan hasil belajar siswa dipengaruhi oleh sarana dan prasarana sekolah yang yang menunjang pembelajaran (Harefa, 2020). Pada pembelajaran kimia, salah satu sarana yang sangat penting adalah laboratorium dengan alat dan bahan yang cukup memadai ( Al Idrus, 2020). Pada beberapa kondisi, guru menganggap penggunaan laboratorium memperlambat proses pembelajaran (Mifran, 2015)

Inovasi pembelajaran yang dilakukan oleh guru kimia berkontribusi dalam pengembangan keterampilan siswa (Silaban, dkk, 2016). Ketrampilan siswa yang dimaksud adalah intelektual dan psikomotor yang dilandasi sikap ilmiah (Saronom, 2021). Karekteristik materi yang akan diajarkan harus disesuaikan dengan model pelajaran yang dapat menolong anak belajar (Purba, 2017). Mempelajari kimia tidak hanya dengan aktivitas menyelesaikan soal rutin sesuai dengan contoh yang diberikan oleh guru, tetapi perlu pula melibatkan aktivitas aktif yang dapat merangsang kemampuan berpikir siswa (Sagala, 2008). Siswa juga harus mampu mengembangkan nilai kreatifitas dan inovatif yang terkait dengan kemampuan psikomotorik siswa (Manalu, dkk., 2016). Salah satu pembelajaran yang dapat merangsang berpikir siswa di dalam kelas dan untuk meningkatkan kreativitas siswa adalah dengan menggunakan metode eksperimen (Simatupang, 2017). Metode eksperimen membuat siswa lebih aktif dalam proses pembelajaran (Azzahra, 2019), sehingga diharapkan meningkatkan hasil belajar siswa.

Metode eksperimen dalam pembelajaran kimia memberi kesempatan kepada siswa, baik perorangan maupun kelompok untuk dilatih melaksanakan suatu percobaan (Bahruddin, 2018). Melalui metode eksperimen, peserta didik mencari

dan menemukan sendiri hasilnya dengan melakukan percobaan (Astuty, dkk., 2012). Dengan memecahkan suatu masalah berpikir kritis, peserta didik mampu membuktikan kebenaran dari teori yang dipelajari secara nyata. Berdasarkan latar belakang yang telah diuraikan di atas maka peneliti melakukan penelitian dengan judul "Peningkatan Hasil Belajar Kimia Siswa Kelas X MIA Melalui Metode Eksperimen.

\section{METODE}

Jenis penelitian ini menggunakan metode quasi experiment (eksperimen semu) yaitu metode yang tidak dapat memberikan kontrol penuh. Dengan desian penelitian pretestposttest eksperiment control design seperti pada tabel 1.

Tabel 1. Desain Penelitian

\begin{tabular}{cccc}
\hline Kelompok & Pre & Treatment & Post \\
\hline $\mathbf{E}$ & $\mathrm{T}_{1}$ & $\mathrm{X}$ & $\mathrm{T}_{2}$ \\
$\mathbf{K}$ & $\mathrm{T}_{1}$ & - & $\mathrm{T}_{2}$ \\
\hline
\end{tabular}

Keterangan :

E : kelompok eksperimen

$\mathrm{K}$ : kelompok kontrol

$\mathrm{T}_{1}$ : pemberian prettest

$\mathrm{T}_{2}$ : pemberian posttest

$\mathrm{X}$ : perlakuan (metode eksperimen)

Teknik pengambilan sampel yang dilakukan dengan cara purposive sampling. Penelitian ini dilaksanakan di SMA Widya Manggala Jakarta. Populasi penelitian ini adalah seluruh peserta didik kelas X MIA SMA Widya Manggala Jakarta. Sampel penelitian ini adalah kelas X MIA1 sebagai kelompok kontrol dan kelas X MIA 2 sebagai kelompok eksperimen.

Teknik pengumpulan data pada penelitian ini adalah dengan menggunakan instrumen soal pilihan berganda sebanyak 20 butir dengan option A, B, C, D dan E. Instrumen soal yang digunakan divalidasi oleh validator ahli, yaitu dosen peneliti evaluasi pembelajaran. Instrumen soal yang digunakan disesuaikan dengan indikator pembelajaran pokok bahasan koloid, seperti yang disajikan pada table 2 .

Tabel 2. Kisi-kisi Intrumen Soal

\section{Indikator}

1. Mengidentifikasi sifatsifat laturanelektrolit dan nonelektrolit melalui percobaan 
Chemistry Education Practice, 4 (3), 2021 - 233

Baru, Purba, Azzahra

2. Mengelompokkan larutan kedalam larutan elektrolit dan nonelektrolit berdasarkan sifat hantar listrik

3. Menjelaskan penyebab kemampuan larutan Elektrolitmenghantarkanar us listrik

4. Mendeskripsikan bahwalarutan elektrolit dapat berupa senyawa ion dansenyawa kovalen polar

Teknik analisis data dalam penelitian ini adalah analisis data deskriptif. Data yang diperoleh pada penelitian diuji homogenitas dan normalitas sebagai prasyarat analisis. Analisis data dilakukan dengan uji $t_{\text {paired }}(\alpha=95 \%)$, dengan menggunakan SPSS 22 untuk mengetahui pengaruh metode eksperiman terhadap peningkatan hasil belajar siswa dengan menggunakan rata-rata setiap indikator kemampuan berpikir kritis kelas kontrol dan kelas eksperimen.

\section{HASIL DAN PEMBAHASAN}

Penelitian ini diterapkan di sekolah SMA Widya Manggala pada kelas X dengan materi larutan elektrolit dan non elektrolit, sehingga populasi penelitian adalah seluruh kelas XMIA yang berjumlah dua kelas sebanyak 38 siswa dengan jumlah siswa yang masuk sebanyak kelas sebanyak 31 selama penelitian berlangsung. Dari hasil penelitian hasil penelitian diolah dengan menggunakan uji statistik. Data hasil pretest penelitian disajikan data seperti pada gambar 1 :

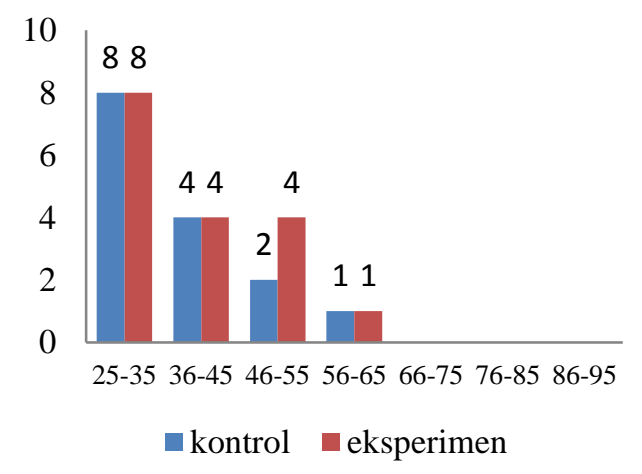

\section{Gambar 1. Data Pretes}

Dari hasil pengolahan data diketahui pada kelas eksperimen skor pretest terendah 25 dan skor tertinggi 65 dengan rata-rata 42,2. Untuk melihat perbedaan skor pretest dan posttest, maka data posttest hasil penelitian disajikan dalam gambar 2 dibawah ini:

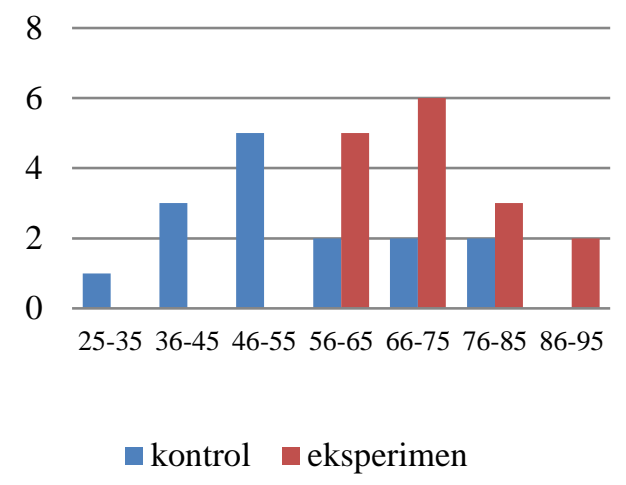

Gambar 2. Data Postes

Skor postes di kelas eksperimen terendah 65 dan tertinggi 95 dengan rata-rata 73,12 .

Pada prettest kelas eksperimen $100 \%$ tidak tuntas atau tidak mencapai KKM kerena belum memahami materi, kurang mengerti dan setelah diberikan perlakuan pada kelas eksperimen 43,75 siswa tuntas atau mencapai KKM. karena sudah diberikan perlakuan. Pada kelas kontrol dari hasil data diketahui nilai prettest terendah 25 dan nilai tertinggi 65 dengan rata-rata 39,33 . Sedangkan nilai skor posttest di kelas kontrol terendah 35 dan tertinggi 85 dengan rata-rata 58. Pada prettest kelas kontrol $100 \%$ tidak tuntas atau tidak mencapai KKM kerena belum dipelajari oleh siswa. Sedangkan pada posttest kelas kontrol $20 \%$ siswa tuntas atau mencapai nilai KKM.

Hasil uji prasyarat yaitu normalitas pada penelitian ini disajikan dalam tabel 3 dibawah ini:

Tabel 3. Uji Normalitas

\begin{tabular}{lccc}
\hline \multirow{2}{*}{ Kelas } & \multicolumn{3}{c}{ Shapiro-Wilk } \\
\cline { 2 - 4 } Eksperimen & Statistic & df & Sig. \\
Kontrol &, 921 & 16 &, 174 \\
\hline
\end{tabular}

Berdasarkan tabel diatas, nilai signifikansi masing-masing kelas 0,174 dan 0,269 dlebih besar dari nilai probabilitas sebesar 0,05 . Dengan demikian dapat disimpulkan bahwa kedua kelompok berdistribusi normal karena memenuhi kriteria Sig.> 0,05.

Uji prasyarat selanjutnya adalah uji homogenitas, yang disajikan pada tabel 4 dibawah ini:

Tabel 4. Uji Homogenitas 


\begin{tabular}{rrrrr}
\hline & $\begin{array}{c}\text { Levene } \\
\text { Statistic }\end{array}$ & df1 & df2 & Sig. \\
Pretes &, 220 & 1 & 29 &, 643 \\
\hline
\end{tabular}

Berdasarkan tabel 4 diperoleh nilai signifikan (Sig.) pretes sebesar 0,643. Hal ini menunjukan bahwa nilai Sig. lebih besar dari pada taraf signifikan sebesar 0,05 artinya varians bersifat homogen.

Setelah diperoleh hasil pengujian prasyarat analisis data, dapat dinyatakan bahwa kedua data tersebut berdistribusi normal dan homogen. Pengujian hipotesis digunakan uji statistik parametris paired samples test dengan kriteria pengujian, jika nilai Sig (2-tailed) > probabilitas 0.05, maka tidak ada perbedaan atau Ho diterima dan jika Sig (2-tailed) < probabilitas 0.05 maka terdapat perbedaan atau Ha diterima. Berdasarkan hasil uji hipotesis, diperoleh nilai Sig.(2-tailed) $0.000<$ probabilitas 0.05. Artinya terdapat peningkatan signifikan dengan dengan demikian Ho ditolak dan Ha diterima. Peningkatan hasil belajar di kelas kontrol sebesar 0,31 sedangkan untuk kelas eksperimen sebesar 0,51 dan masing masing kedua kelas tersebut sama - sama masuk dalam kategori sedang.

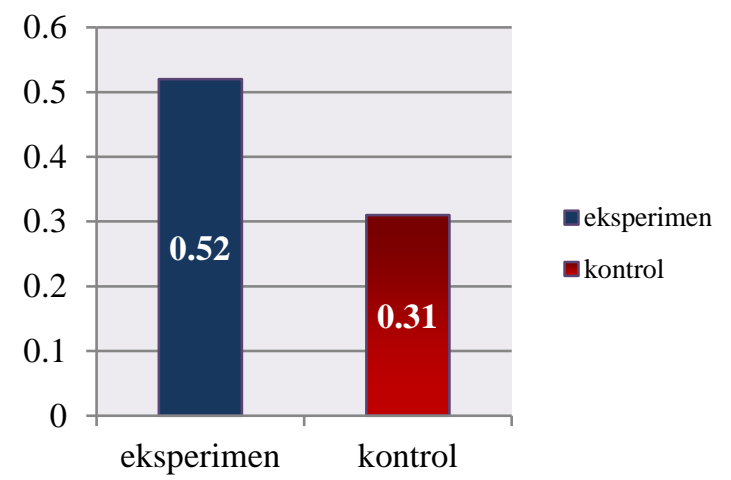

Gambar 3. Grafik Nilai Gain

Kurangnya motivasi siswa dalam menjawab soal posttest kelas kontrol dan menyebabkan penurunan hasil posttest siswa di kelompok kontrol karena pembelajaran yang hanya satu arah atau hanya guru lebih aktif dalam pembelajaran sedangkan siswa lebih banyak mendengarkan dan tidak adanya timbal balik antara siswa dan guru.

Selama pembelajaran berlangsung muncul beberapa pertanyaan-pertanyaan dari siswa tetapi pertanyaan tersebut tidak langsung dijawab secara langsusung oleh guru melainkan guru memberikan umpan balik yang mengarah kepada siswa untuk menggali konsep awal yang dimiliki oleh siswa, sehingga pada akhirnya jawaban yang mereka kehendaki dari guru terjawab dengan sendirinya oleh mereka.

Pada tahap tantangan, guru memberikan kesempatan kepada setiap kelompok untuk melakukan eksperimen atau percobaan didalam kelas dengan panduan (LKS) lembar kerja siswa yang didampingi oleh guru. Kelompok lain diminta untuk melihat hasil kerja yang telah dilakukan oleh kelompok yang mengerjakan eksperimen sehingga kelompok yang lain bisa mengerjakan atau menyelesaikan eksperimen tersebut.

Pada tahap penerapan, guru memberikan kesempatan kepada siswa untuk menggunakan pemahaman konseptual yang baru diperolehnya kedalam konteks lain. Pada tahap ini juga sebagai evaluasi proses selama pembelajaran yang dilakukan sehingga dapat dilihat apakah siswa sudah mencapai tujuan pembelajaran atau belum. Untuk itu guru memfasilitasi siswa dengan pemberian tugas secara individu yang berfungsi sebagai lembar evaluasi. Selain melakukan evaluasi secara tertulis juga melakukan evaluasi dalam bentuk hasil pengamatan selama proses pembelajaran berlangsung guna meyakinkan sejauh mana siswa memahami materi yang diberikan selama proses pembelajaran berlangsung.

Hasil pengamatan pembelajaran dengan menggunakan metode eksperimen menunjukkan sikap positif baik dipertemuan pertama maupun pertemuan akhir. Hal-hal yang diamati meliputi konsentrasi belajar dalam pembelajaran, perhatian siswa selama melakukan percabaan dalam kelompok, interaksi satu sama lain, disiplin dalam melakukan eksperimen dan kerjasama dalam kelompok serta adanya kemauan untuk bertanya dan berpendapat.

Pada kelas kontrol diterapkan model pembelajaran konvensional yakni cerama bermakna dan tanya jawab. Proses pembelajaran pada kelas kontrol berlangsung dalam satu hari selama 3 jam pertemuan. Penerapan model ceramah memberikan kesempatan yang lebih banyak bagi guru dalam mengambil peran selama proses pembelajaran betrlangsung, sehingga aktivitas siswa berkurang. Siswa hanya menerima apa saja yang disampaikan oleh guru dengan sedikit respon, baik berupa pertanyaan ataupun tanggapan dari siswa.

Hasil penelitian dan pengamatan menunjukkan bahwa beberapa siswa kelas kontrol memiliki ketertarikan dan antusias belajar hampir sama dengan kelas eksperimen selama proses pembelajaran berlangsung, akan 
tetapi sebagian besar yang lain memperlihatkan hasil sebaliknya, yakni lebih rendah dari kelas eksperimen dikarenakan di kelas kontrol banyak siswa yang kurang memberi respon.

\section{SIMPULAN}

Berdasarkan hasil analisis dan pembehasan dapat ditarik kesimpulan sebagai berikut bahwa 1) Terdapat peningkatan hasil belajar kimia siswa dengan menggukan metode eksperimen dengan nilai rata-rata pretes 42,2 dan postes sebesar 73,12. Sementara nilai pretes kelas kontrol dengan nilai rata-rata 39,33 dan postes sebesar 58 dan hasil uji t dengan metode eksperimen terdapat peningkatan signifikan. 2) Peningkatan hasil belajar kimia siswa melalui metode eksperimen dengan besar peningkatan sebesar 0,51 untuk kelas eksperimen sedangkan 0,31 untuk kelas kontrol dan masing masing kedua kelas tersebut masuk dalam kategori sedang.

\section{SIMPULAN}

metode

Bagi peneliti berikutnya, dalam menerapkan oleh guru.

\section{DAFTAR PUSTAKA}

Al Idrus, S. W., Anwar, Y. A. S., Hakim, A., \& Saprizal, S. (2020). Penulisan Artikel Ilmiah Sebagai Upaya Peningkatan Profesionalisme Guru Kimia SMA di Kota Mataram. Jurnal Pengabdian Masyarakat Sains Indonesia, 2(1).

Anwar, Y. A. S. (2019). Pengaruh Model Pembelajaran Predict-Observe-Explain (POE) Terhadap Pemahaman Konsep Siswa Materi Kesetimbangan Kelarutan Kelas XI MIA SMAN 2 Labuapi Tahun Ajaran 2017/2018. Chemistry Education Practice, 1(2), 27-35.

Astuti, R., Sunarno, W., \& Sudarisman, S. (2012). Pembelajaran IPA dengan Pendekatan Ketrampilan Proses Sains Menggunakan Metode Eksperimen Bebas Termodifikasi dan Eksperimen Terbimbing. In Seminar Nasional Pendidikan Sains V 2015. Sebelas Maret University.

Azzahra, S. F. (2019). Peningkatan kemampuan berfikir kritis siswa melalui pembelajaran eksperimen pada materi larutan elektrolit dan non elektrolit. EduMatSains: Jurnal
Pendidikan, Matematika dan Sains, 4(1), 77-88.

Bahruddin, B. (2018). Dampak Pembelajaran Eksperimen Kimia Terhadap Minat dan Hasil Belajar Siswa. Andragogi: Jurnal Diklat Teknis Pendidikan dan Keagamaan, 6(1), 19-40.

Harefa, N. (2018). Hubungan motivasi belajar terhadap keterampilan pemecahan masalah siswa pada metode praktikum. Jurnal Selaras: Kajian Bimbingan dan Konseling serta Psikologi Pendidikan, 1(1), 28-38.

Islamiati, N., Rahmawati, R., \& Haris, M. (2020). Pengaruh Model Pembelajaran Berbasis Masalah Terhadap Hasil Belajar Kimia Siswa Kelas X MS SMAN 1 Kediri Pada Materi Reaksi Reduksi Dan Oksidasi. Chemistry Education Practice, 3(2), 112-115.

Junita, Y., \& Purba, L. S. L. (2019). Peningkatan Hasil Belajar Kimia Siswa Melalui Model Pembelajaran Kooperatif Tipe Think Pair Share (Tps) Di SMAN 92 Jakarta. Jurnal Dinamika Pendidikan, 12(1), 41-54.

Manalu, E., Silaban, S., Silaban, R., \& Hutabarat, W. (2016). The development of chemical practice guidebook colloid system-based integrated contextual character values. Jurnal Pendidikan Kimia, 8(2), 87-89.

Mifran. (2015). Pengaruh Penggunaan Metode Eksperimen Terhadap Aktivitas, Motivasi Dan Hasil Belajar Siswa Pada Pokok Bahasan Arus Dan Tegangan Listrik Bolak Balik Di Sma Negeri 3 Yogyakarta Tahun Pelajaran 2014/2015. Jurnal Fisika dan Pendidikan Fisika Vol. 1. no.1 (2015) hal. 32-35

Purba, L. S. L. (2018, September). Analisis Minat Belajar Kimia Pokok Bahasan Sistem Periodik Unsur (SPU) Melalui Pemanfaatan Aplikasi Games Atomas pada Android. In Seminar Nasional Sains dan Pendidikan Sains XI Tahun 2018.

Purba LSL, (2017). Pengaruh Penerapan Model Pembelajaran Tipe Two Stay-Two Stay (TS-TS) terhadap Hasil Belajar dan Aktivitas Belajar Siswa pada Pokok Bahasan Koloid. Jurnal Pendidikan, 
Matimatika dan Sains. Vol.1 No 2. Hal 150

Purba, L. S. L. (2014). Pengembangan Buku Ajar Kimia SMA/MA Kelas XII Semester I Berdasarkan Kurikulum 2013 (Doctoral dissertation, UNIMED).

Sagala, S. (2008). Konsep dan Makna Pembelajaran. Bandung: CV Alfabeta

Silaban, R., Pasaribu, M., Sitompul, S. M., \& Simanullang, T. W. (2016). Inovasi Lembar Kerja Siswa Reaksi Redoks Berbasis Pemecahan Masalah Untuk Siswa SMA. Jurnal Pendidikan Kimia, 8(1), 6570.

Silaban, S. (2021). Pengembangan program pengajaran. Yayasan Kita Menulis.

Simatupang, N. I. (2017). Penerapan metode eksperimen terhadap peningkatan hasil belajar kimia siswa pada materi laju reaksi. Jurnal Pendidikan Kimia, 9(2), 318322.

Sutrisno, V. L. P., \& Siswanto, B. T. (2016). Faktor-faktor yang mempengaruhi hasil belajar siswa pada pembelajaran praktik kelistrikan otomotif SMK di Kota Yogyakarta. Jurnal pendidikan vokasi, 6(1), 111-120.

Undang-Undang Nomor 14 Tahun 2005 tentang Guru dan Dosen. Jakarta, PT Media Pustaka Mandiri.

Undang-undang Republik Indonesia No. 20 tahun 2003. Sistem Pendidikan Nasional (Sisdiknas). Jakarta: Sinar Grafika

Widodo, W., \& Widayanti, L. (2013). Peningkatan aktivitas belajar dan hasil belajar siswa dengan metode problem based learning pada siswa kelas viia mts negeri donomulyo kulon progo tahun pelajaran 2012/2013. Jurnal Fisika Indonesia UGM, 17(49), 80105. 